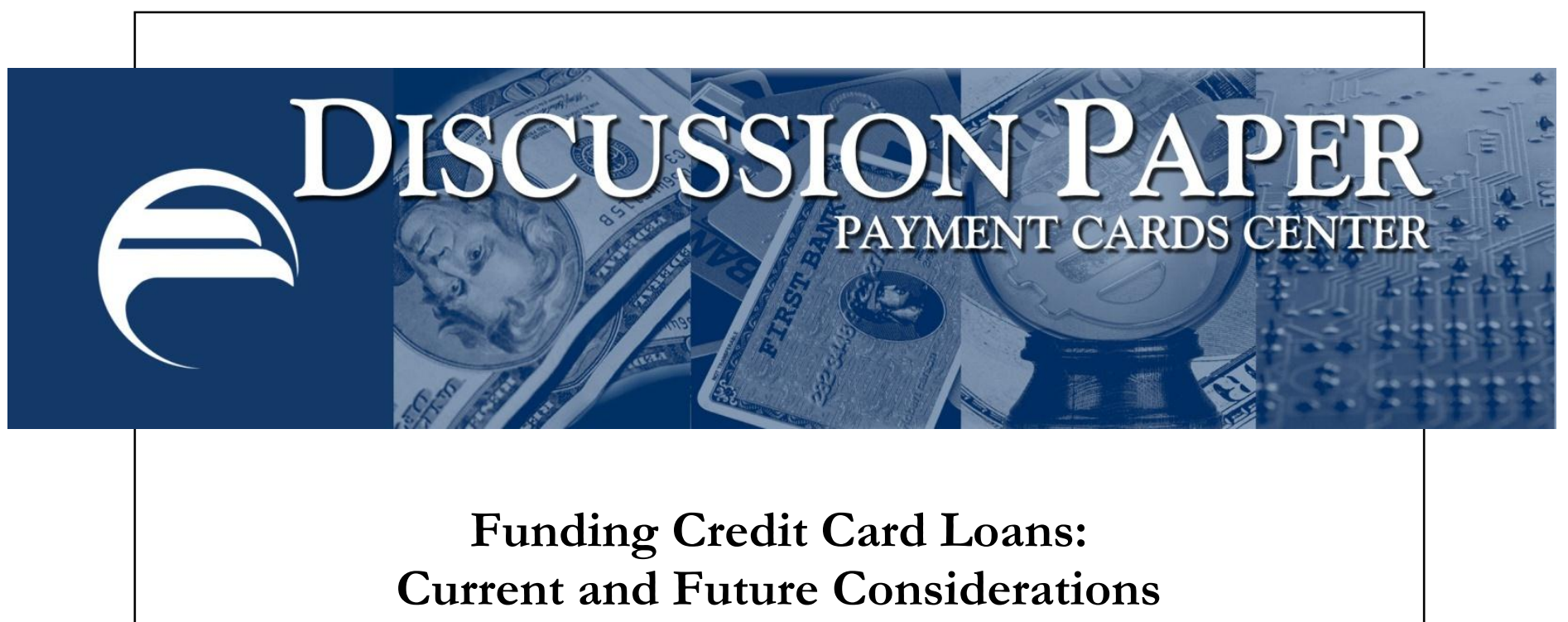

James van Opstal*

\title{
November 2013
}

Summary: Many factors influence credit-card-issuing banks' decisions about how to fund credit card loans. These factors include the size and structure of the institution, economic conditions, and the regulatory environment. Against the backdrop of a much smaller market for credit card asset-backed securitization, the Payment Cards Center (PCC) wanted to better understand how changes in any of the above factors and in the funding sources accessible to credit-card-issuing banks are affecting funding strategies now and in the future. To gain this perspective, the PCC interviewed a diverse set of credit-card-issuing bank executives. These participants were asked about the composition of their funding sources, changes in the markets for these sources of funds, and the effects of existing or potential regulation. This paper presents several themes that emerged from these discussions.

Keywords: credit cards, securitization, deposits, funds transfer pricing, liquidity risk, capital standards

JEL Classification Numbers: G21, G28, G32

* Payment Cards Center, Federal Reserve Bank of Philadelphia, Ten Independence Mall, Philadelphia, PA 19106 E-mail: bob.hunt@phil.frb.org.

The views expressed here are those of the author and do not necessarily reflect the views of the Federal Reserve Bank of Philadelphia or the Federal Reserve System. No statements in this paper should be treated as legal advice. The author greatly appreciates the contributions of those who participated in the interviews described in the paper. Thanks also to Bob Hunt and Julia Cheney for their insights and helpful comments. This paper is available free of charge at www.philadelphiafed.org/payment-cards-center/publications/discussion-papers/.

\section{FEDERAL RESERVE BANK OF PHILADELPHIA}

Ten Independence Mall, Philadelphia, PA 19106-1574 • (215) 574-7220 • www.philadelphiafed.org/payment-cards-center/ 


\section{Introduction}

In 2002, the Payment Cards Center (PCC) hosted a workshop to discuss U.S. credit card assetbacked securities (ABS) and key issues facing ABS markets at the time. The PCC organized this discussion because securitization of credit card assets had become the primary funding vehicle used by many lenders with substantial credit card portfolios. ${ }^{1}$ Today, the securitization of credit card receivables remains an important source of funding for many issuers, but it is no longer the primary funding vehicle for these assets. The level of credit card ABS outstanding in the U.S. has fallen substantially from \$324 billion in 2007 to $\$ 128$ billion in $2012 .^{2}$ This reconstitution in funding strategy by credit card issuers can be traced to several developments in the ABS market - including both regulatory and accounting rule changes - as well as to a response by issuers to broader economic conditions since the beginning of the financial crisis and during the recent postrecessionary period.

The replacement of securitized funding by alternative sources motivated an interest in revisiting the earlier workshop discussion. To that end, the PCC conducted a series of interviews with executives at a number of credit-card-issuing banks. These participants were asked about the composition of their funding sources, developments in the markets for these and alternative sources of funds, and the effects of recent or pending regulation on their funding decisions. Participants shared observations on a wide range of market and regulatory developments influencing their funding strategies. Their comments significantly informed the issues examined in this paper. ${ }^{3}$ These industry perspectives can help researchers better understand the complex forces affecting how these funding decisions are made by credit-card-issuing banks.

\footnotetext{
${ }^{1}$ Mark Furletti, “An Overview of Credit Card Asset-Backed Securities," Federal Reserve Bank of Philadelphia Payment Cards Center Discussion Paper, December 2002. Data from the Federal Reserve Board's monthly statistical release (G19) suggest that, over the period 2000-2010, 50 percent of revolving credit was held in pools of securitized assets.

${ }^{2}$ Data were obtained from the Securities Industry and Financial Markets Association (SIFMA). For more information, see www.sifma.org/research/statistics.aspx.

${ }^{3}$ This paper will describe insights learned from these conversations, but the specific institutions and participants will remain anonymous.
} 
The remainder of the paper is organized as follows. Section II describes the diversity of financial institutions with credit card operations and some of the various sources of funds these banks access. Section III provides an overview of funds transfer pricing, a mechanism used by many nonmonoline banks to allocate funds to credit card operations. Section IV discusses several regulatory factors that have implications for funding decisions. Section V presents developments in the securitization market and industry views on credit card ABS as a continued source of funds. Section VI describes how the current interest rate environment affects funding with deposits. Finally, section VII concludes the paper.

\section{Credit-Card-Issuing Banks and Funding Sources}

The set of banks that issue credit cards are diverse with respect to both the size of the institution and the business lines in which the bank (or its holding company) engages. This diversity has implications for the types of funding sources to which a credit card issuer has access and, ultimately, which it chooses to fund its credit card business. As of December 31, 2012, the Federal Financial Institutions Examinations Council (FFIEC) listed 18 banks in the credit card specialty bank peer group with assets ranging from approximately $\$ 170$ million to just over $\$ 160$ billion. $^{4}$ Although these banks share a focus on credit card lending, the size of this business and its role within larger corporate structures will be different and have important implications for funding decisions.

For example, a monoline credit card bank, or a bank specializing primarily in credit card lending, generally will not have access to funding alternatives such as retail deposits. Instead, in most cases a monoline must rely more on wholesale funding sources, such as securitization, because it lacks other retail sources of funds, such as deposits from a branch network. Alternatively, credit card operations may be contained within one or more subsidiaries of a bank holding company. In this structure, the credit card subsidiary bank may or may not engage in other lines of business besides credit card lending. Regardless, the various businesses and actions of the parent holding company and its other subsidiaries can provide

\footnotetext{
${ }^{4}$ These data are from the FFIEC Uniform Bank Performance Report (UBPR). Some of the banks listed in this category are part of larger bank holding companies. To access the UBPR, see www.ffiec.gov/ubpr.htm.
} 
access to diversified sources of funding. In contrast to monoline credit card banks, the credit card arm of a large, diversified bank would have more access to funds sourced from consumer, commercial, and investment lines of business through an allocation process conducted by the parent company. These distinctions lead to differences in the mix of funding sources. In addition, the relative costs of these funding sources for credit card business lines may vary significantly depending on the structure of the financial institution.

Two important funding sources used by credit-card-issuing banks are securitization and deposits — both are described below. Of course, these banks also use many other types of funding, including Federal Home Loan Bank advances and unsecured debt as part of increasingly sophisticated and diversified funding strategies. ${ }^{5} \mathrm{We}$ focus on securitization and deposit-based alternatives because they were the broad categories common to the set of diverse credit card issuers we engaged in our interviews.

\section{Securitization}

Credit card securitization is a mechanism by which credit-card-issuing banks pool credit card receivables and raise funds by selling securities backed by the cash flows generated from those receivables. The process involves a bank pledging its credit card receivables to a "bankruptcy remote" special purpose entity (SPE). ${ }^{6}$ The SPE issues securities in exchange for investor funds and sends these funds back to the credit-card-issuing bank. In the case of credit card securitized assets, the SPE typically takes the form of either a master or issuance trust. ${ }^{7}$ These trust structures provide credit-card-issuing

\footnotetext{
${ }^{5}$ For a discussion of bank liabilities and funding, see Christine M., Bradley and Lynn Shibut, "The Liability Structure of FDIC-Insured Institutions: Changes and Implications," FDIC Banking Review. 18:2 (2006) at www.fdic.gov/bank/analytical/banking/2006sep/br18n2full.pdf.

6 "Bankruptcy remote" refers to the legally distinct nature of the special purpose entity (SPE) such that the pledged receivables transferred to the SPE are not available to general creditors of the credit-card-issuing bank.

${ }^{7}$ The primary difference between a master and issuance trust is that the collateral backing the issuance trust is a collateral certificate with a claim on a pool of credit card receivables, rather than the pool of receivables itself. There is more flexibility in an issuance trust because a senior/subordinated structure is not required for each series and as long as trust-level credit enhancements are met, the trust can issue senior series without subordinated series. For more information, see Tarun Sabarwal, "Common Structures of Asset-Backed Securities and Their Risks," Corporate Ownership \& Control, 4:1 (Fall 2006) at //people.ku.edu/ sabarwal/sabarwal_abs_published.pdf.
} 
banks with greater latitude in choosing when to issue ABS and with flexibility to issue credit card ABS with maturities of two, three, five, seven, or even 10 years.

Securitization funding provides additional benefits to banks. First, the process of isolating securitized credit card receivables allows the bank to partially separate the credit risk of the securitized assets from the credit risk of the bank. ${ }^{8}$ This characteristic of securitization, along with various credit enhancements, allows the credit-card-issuing bank to acquire higher ratings for these ABS than it might receive on its own unsecured corporate debt. ${ }^{9}$ As a result, a bank may be able to reduce its total funding costs associated with its credit card line of business. Second, securitizing credit card receivables also provides a degree of investor diversification because it creates financial instruments attractive to a distinct segment of fixed-income investors. Historically, securitization has been an important funding source for banks with limited access to deposit-based funding as well as for banks aiming to achieve more diversification in the investor segments that provide their funding.

\section{Deposit-Based Alternatives}

Banks' deposits may vary in a number of ways. For example, the strength of the deposit relationship with customers may be influenced by the degree to which a particular customer is price sensitive or the number of relationships a bank has with this customer (for example, having a deposit account, savings account, mortgage, etc.). The fewer relationships the customer has and/or how price sensitive a customer is may have implications for how likely the customer is to switch to an alternative provider. In developing a funding strategy, a distinction is often made between core deposits and brokered deposits. Very generally, core deposits are considered to be more stable (less likely to move to another

\footnotetext{
${ }^{8}$ For a number of reasons, the separation is not complete. For example, there is the seller's interest in the master trust. Excess spread (see footnote 9) may also be affected by changes in the performance of the issuing bank.

${ }^{9}$ Examples of credit enhancements include overcollateralization, excess spread, and letters of credit. For more detail about internal and external credit enhancement facilities, see Chapter VI of the FDIC's Credit Card Securitization Manual at www.fdic.gov/regulations/examinations/credit_card_securitization/ch6.html.
} 
bank given a change in relative interest rates). ${ }^{10}$ Brokered deposits are considered to be more at risk to competitive offers by other providers.

Core and brokered deposits — and the differences between these two alternative funding sources for credit card receivables — are described in more detail below. In addition, Internet deposits - a channel increasingly used as a source of funding — are discussed particularly in the context of how industry perspectives are evolving with respect to the stability of deposits sourced through this channel.

\section{Core Deposits}

In assessing liquidity and funds management, the FDIC uses a particular definition of core deposits for its Uniform Bank Performance Report. ${ }^{11}$ As of March 31, 2011, this definition of core deposits equals the sum of demand deposits, all negotiable order of withdrawal and automatic transfer service accounts, money market deposit accounts, other savings deposits, and time deposits under $\$ 250,000$, minus all brokered deposits under $\$ 250,000 .{ }^{12}$ In practice, however, the economic distinction of a core deposit to a bank can differ from the regulatory definition used by the FDIC. Internally, banks also may classify their deposit accounts along broader measures of stability and reliability considering the motivations of the depositor.

There has been debate as to what should be considered a core deposit. The FDIC "Study on Core Deposits and Brokered Deposits" describes several qualities characteristic of core deposits. One such characteristic is that core deposits are less sensitive to interest rates and reprice more slowly when interest rates rise. In addition, core deposits are generally placed by local customers or depositors who have other established relationships with the bank, making withdrawal less likely. While core deposits provide a

\footnotetext{
${ }^{10}$ Throughout this paper, the term "stability" will be used to describe the interest rate sensitivity of deposits or depositors.

${ }^{11}$ See Section 6.1 - Liquidity and Funds Management of the FDIC's Risk Management Manual of Examination Policies at https://www.fdic.gov/regulations/safety/manual/section6-1.html. The manual was last updated in October 2012.

${ }^{12}$ FDIC. "Study on Core and Brokered Deposits," FDIC (2011). pp. 4-5.
} 
reliable funding base, market competition can make efforts to grow and retain core deposit bases expensive.

\section{Brokered Deposits}

Brokered deposits are defined by the FDIC as deposits "obtained, directly or indirectly, from or through the mediation or assistance of a deposit broker" ${ }^{\prime 13}$ who engages in the business of placing deposits with insured depositories, typically at a rate higher than most retail deposits. The advantage of brokered deposits over core deposits is the speed and ease with which a bank can raise deposits. Brokered deposits allow banks to access a larger deposit market geographically and to accept deposits in larger blocks rather than through individual depositors. However, they are considered more volatile sources of funding because of the sensitivity to interest rates exhibited by most investors in brokered deposits. Providers of brokered deposits tend to be more sensitive to changes in the interest rate environment as well as in the bank's credit risk profile and are more likely to curb or withdraw funds in favor of more attractive investments. ${ }^{14}$ As a result, the FDIC restricts acceptance of brokered deposits as well as the interest rates that can be paid on these deposits by banks that are not well capitalized.

\section{Internet Deposits}

Historically, regulators have classified deposits raised via the Internet as brokered deposits rather than core deposits. This classification was based on the expectation that these depositors are more interest rate sensitive than those who open their accounts at a physical branch. This expectation was likely sensible more than a decade ago. In its Risk Management Manual of Examination Policies (last updated in October 2012), the FDIC explains that Internet deposit customers "may have no other relationship with the bank and have no loyalty with their deposit funds. If more attractive returns become available, these

\footnotetext{
${ }^{13}$ See 12 C.F.R. $\$ 337.6(a)(2)$.

${ }^{14}$ See Section 6.1 - Liquidity and Funds Management (subheading "Funding Sources: Liabilities") of the FDIC's Risk Management Manual of Examination Policies at www.fdic.gov/regulations/safety/manual/section61.html\#liabilities.
} 
customers may rapidly transfer funds to new institutions or investments in a manner similar to that of wholesale investors." 15

More recently, however, this view is being reexamined. In a Core and Brokered Deposits Roundtable held by the FDIC in 2011, several industry participants suggested that Internet deposits are simply a different channel through which a customer can communicate with the bank. ${ }^{16}$ One argued that, regardless of the channel, a direct retail relationship with the customer, in which the customer personally makes the deposit, should make Internet deposits stickier, at least relative to brokered deposits. ${ }^{17}$ Further, it was argued that the broader characteristics of the deposit base, including price, maturity, and

relationship, are more important than the channel when considering the volatility of the funds. ${ }^{18}$ As banks continue to grow their Internet deposits and collect more data, the characteristics and sensitivity of these deposits will likely become clearer.

\section{Funds Transfer Pricing}

Card-issuing-banks with the ability to access funding from across various business lines often use a mechanism known as funds transfer pricing. Funds transfer pricing typically involves a "central treasury" group that buys funds from deposit (or other liability-based) lines of business for a funds transfer credit and sells funds to lending (or other asset-based) lines of business at a funds transfer price. A bank's calculation of a funds transfer price is often based on a reference rate or curve representing the

\footnotetext{
${ }^{15}$ See Section 6.1 - Liquidity and Funds Management (subheading "Brokered and Rate Sensitive Deposits") of the FDIC's Risk Management Manual of Examination Policies at www.fdic.gov/regulations/safety/manual/section61.html\#liabilities.

${ }^{16}$ According to the 2010 SCF, 61 percent of households conduct business with at least one of their financial institutions via computer. See Loretta Mester, "Changes in the Use of Electronic Means of Payment: 1995-2010," Federal Reserve Bank of Philadelphia, Business Review (Third Quarter 2012).

${ }^{17}$ The transcript of the FDIC's Core and Brokered Deposits Roundtable is available at http://www.fdic.gov/regulations/reform/3-18-11transcript.pdf. See comments by Todd Sandler on page 47.

${ }^{18}$ See comments by Chris Whalen on page 45 of Core and Brokered Deposits Roundtable transcript.
} 
bank's cost of funds. Then, the bank adjusts that rate to incorporate risks, including liquidity characteristics and embedded options. ${ }^{19}$

Funds transfer pricing allows a bank to centralize the management of interest rate and liquidity risk in the treasury group, which has the expertise and ability to hedge these risk exposures. ${ }^{20}$ It also facilitates a bank's ability to measure the profitability of each line of business by separating out the effects of changes in market interest rates from product pricing and business performance. Because different lines of business carry different duration and liquidity risks, the funds transfer price provides a mechanism to capture these risks in the cost of funds charged to individual business units.

Despite similar concepts and calculations, implementation of funds transfer pricing is institutionspecific, varying widely depending on the size, nature, and complexity of the bank. For example, the choice of reference rate employed as a starting point in the calculation of its fund transfer prices influences the design of a bank's transfer pricing model. Many banks rely on LIBOR (London Interbank Borrowing Rate). ${ }^{21}$ Other banks consider brokered CDs to be the best approximation of the marginal cost of funds for credit card assets. Large banks may construct a unique marginal cost of funds curve based on many data points, while smaller banks may rely on one of the standard market rates described above to approximate their cost of funds. ${ }^{22}$ Additionally, as the liquidity and credit characteristics of the balance sheet differ between banks, the fund transfer pricing models employed will account for this variation.

While the participants in our interviews discussed a diversity of approaches to funds transfer pricing, they made a few common observations specific to the funding of credit card businesses. For example, more sophisticated funds transfer pricing models distinguish between two types of credit card

\footnotetext{
${ }^{19}$ For a helpful diagram and explanation, see Robert J. Wyle and Yaakov Tsaig, "Implementing High Value Funds Transfer Pricing Systems," Moody's Analytics (September 2011), p. 13.

${ }^{20}$ Participants suggested some variation in the degree to which the management of these risks are concentrated in the treasury function or shared with the business lines.

${ }^{21}$ LIBOR, or the London Interbank Offered Rate, is an estimate of the average interest rate charged to banks for borrowing from other banks in the London interbank market.

${ }^{22}$ See Wyle and Tsaig (September 2011), p. 8.
} 
balances. The first represents revolving balances - balances that are carried over from one billing cycle to another and on which interest is charged to the cardholder. The second relates to transactional balances balances that are paid in full each billing cycle and on which interest is not charged to the cardholder. ${ }^{23}$

A funds transfer pricing model may associate the characteristics of revolving balances to a variable interest rate on assets that are frequently repriced (today most credit card interest rates are set as a premium over a market rate with reset intervals specified in the consumer contract). ${ }^{24}$ Somewhat paradoxically, transactional balances may be associated with a fixed interest rate (essentially zero, given the grace period that applies to most credit card accounts without a revolving balance) on a longer duration asset. That is, because even though these transactional balances are paid off every month, there is so much persistence in the way that consumers use their cards for transactional purposes that the sequence of these balances behaves more like an asset of much longer duration. As a result, funds transfer pricing may be adjusted to meet the fixed versus floating rate and long- versus short-term duration needs of these two forms of balances.

Another common observation was that credit card securitization can help banks manage their liquidity. The ability to essentially convert credit card loans into liquid investments through securitization reduces the liquidity costs associated with holding these assets on a bank's balance sheet. As a result, well-maintained access to the securitization market can decrease the liquidity premium attached to the funds transfer price that credit card assets receive. ${ }^{25}$ Funds transfer pricing thereby reflects the option value securitization can add to the bank through a lower cost of funds to the credit card line of business. This last point, in particular, demonstrates the importance of funds transfer pricing as a part of a bank's

\footnotetext{
${ }^{23}$ See Kathleen Johnson, "The Transactions Demand for Credit Cards," The B.E. Journal of Economic Analysis \& Policy, Berkeley Electronic Press, vol. 7:1, (2007) p. 16.

${ }^{24}$ Balances may exhibit a duration of 3-4 years, but the interest rates earned on those balances reprice more frequently. Therefore, the interest rate risk is of shorter duration. Of course, in a competitive environment, banks may not be able to raise interest rates on credit card accounts as rapidly as their cost of funds rise.

${ }^{25}$ See Judit Burucs, "How Can a Medium-Sized Bank Develop Its Own Asset/Liability Risk Management System?" International Finance Corporation, World Bank Group, p. 36.
} 
diversified funding strategy. However, it is just one factor among many considered when making funding decisions.

\section{Regulatory Factors}

Another theme in our discussions was consideration of the role regulation plays in an issuer's decisions about its composition of funding sources and its overall funding strategy. Although regulation of the credit card market is much broader, our conversations with participants focused on three particular regulatory developments because they were identified as having the potential to influence the design of funding strategies by credit card issuers. First, some participants expressed concern that the proposed amendments to regulation $\mathrm{AB}$ (Regulation $\mathrm{AB}$ II) may require disclosures that could reduce their willingness to access securitization markets. Second, participants described the limitations on the use of covered bonds as a funding source in the U.S. due to the lack of a regulatory and legal framework. Third, participants described how the implementation of the Basel III standards significantly alters the relative benefits and costs of certain funding sources. These observations on regulation are not exhaustive, but rather a sampling of the ways in which regulation can affect decisions credit-card-issuing banks make about how to fund their businesses.

\section{Regulation $A B I I$}

The SEC originally proposed Regulation AB II in April 2010 to make revisions to the offering process, disclosure, and reporting of ABS, but then reproposed the rule in July 2011 to incorporate earlier comments and Dodd-Frank provisions. ${ }^{26}$ While a key feature of Regulation AB II is the disclosure of asset-level information, credit card securitizations are excluded due to the flexible nature of master and issuance trusts noted earlier. Instead, Regulation AB II requires the disclosure of "grouped account data" for credit card assets, which would combine assets into standardized groups based on similar

\footnotetext{
${ }^{26}$ The SEC has not indicated when the final rule will be issued. It has received more than 50 comments on the reproposed rule, in addition to nearly 200 comments on the original proposed rule.
} 
characteristics and provide data about each group. Especially with the more limited use of credit ratings mandated by Dodd-Frank, the goal of this requirement is to improve investor protections by facilitating investor analysis and due diligence.

In our discussions, a number of participants made particular mention of Regulation AB II because of a concern that the granularity of the required disclosures might result in the exposure of proprietary information. Specifically, the grouped account data in the SEC's proposal would designate segments based on credit score, number of days past due, account age, and state (if in the top 10 states by aggregate balances). Then, for a set of characteristics based on each of these segments, a grouped account would be created and data describing the aggregate credit limit, aggregate account balance, number of accounts, weighted average APR, and weighted average net APR provided to investors. ${ }^{27}$ Participants explained that a disclosure that includes pricing by tiers of credit score would reveal too much about their underwriting models for credit card lending. This discussion suggests the potential of a trade-off associated with disclosure requirements of this sort. On one hand, investors and the securitization market may benefit from more granular data than the pool-level data currently disclosed. On the other hand, this degree of transparency about underwriting strategy may inhibit lenders from securitizing their receivables. ${ }^{28}$ In its requests for comment, the SEC acknowledged these concerns and requested comments on the appropriateness of the proposed segments. ${ }^{29}$

\footnotetext{
${ }^{27}$ For a description and diagram of grouped account data, see Asset-Backed Securities, Proposed Rule, 75 Federal Register 23373 (May 3, 2010).

${ }^{28}$ The American Securitization Forum (the "Forum") submitted a comment letter on August 2, 2010 in response to the Securities and Exchange Commission's request for comment to the "Proposing Release" related to offering, disclosure, and reporting requirements for asset-backed securities under the Securities Act of 1933. In this letter, the Forum described the concerns of its members about the balance between providing detailed metrics on ABS performance and disclosure of proprietary data to competitors. (See pages 39-40.) In the comment letter, the Forum proposed three reports that its members believed met both objectives. (See page 62.) The American Securitization Forum is "a broad-based professional forum through which participants in the U.S. securitization market advocate their common interests on important legal, regulatory and market practice issues." For more information about the Forum, see the American Securitization Forum website at www.americansecuritization.com.

${ }^{29}$ See "Re-Proposal of Shelf Eligibility Conditions for Asset-Backed Securities, Re-proposed Rule," 76 Federal Register 47968 (August 5, 2011).
} 


\section{Covered Bonds}

In contrast to potentially restrictive regulation, participants described the regulatory environment for covered bonds as insufficient for the development of a market. Covered bonds might provide an alternative funding source and benefit credit-card-issuing banks through added funding diversity with a liquid market and greater control over the collateral. In a covered bond, the bank retains ownership and control over a covered pool of credit card receivables, and investors in the pool receive statutory protections in the case of bank insolvency. A crucial characteristic of covered bonds is the provision of dual recourse to the investor. Dual recourse benefits investors as it makes claims on the cash flows of both the bank and the separate cover pool of assets. In the event of bank insolvency, investors have recourse to the cover pool, and if the assets underperform, investors also have unlimited recourse to the bank. In the U.S., Congress has not legislated protections — such as dual recourse — for investors in covered bonds issued by banks. Covered bond legislation was introduced in both the House and Senate in 2011, but neither bill made it to a floor vote.

While covered bonds are not uncommon in Europe, our participants agreed that an insufficient legal foundation in the U.S. is a major obstacle to the development of a domestic covered bond market. ${ }^{30}$ Several U.S. politicians also seem to agree. For instance, Senator Kay Hagan (D-NC) has said that "until a legislative framework for covered bonds is in place in the U.S., our economy, U.S. lenders and their customers will be unable to benefit for the low-cost funding that covered bonds provide." 31

One participant in our interviews explained that the major obstacle is the extent to which investors can rely on accessing the collateral in the event of bankruptcy. Without formalized rights to the

\footnotetext{
${ }^{30}$ For a detailed explanation of the European covered bond market, see the 2012 European Covered Bond Fact Book presented by the European Covered Bond Council (ECBC). The ECBC provides a download of the free electronic copy of the fact book at http://ecbc.hypo.org/Content/default.asp?PageID=501.

${ }^{31}$ Jerry Marlatt, Jeremy Jennings-Mares, Pater Green, et al., "An Analysis of Covered Bonds and the U.S. Market," Morrison \& Foerster (UK) LLP (2013). Available at www.mofo.com/files/Uploads/Images/130225-Analysis-ofcovered-bonds-and-US-market.pdf.
} 
cover pool, the participant added, a covered bond investment effectively lacks dual recourse and may not provide any more protection than an unsecured claim against the bank. This could be addressed by legislation assigning responsibility to the FDIC (or some other covered bond regulator) to separate the cover pool of assets from the other assets of a defaulting bank if that bank enters receivership and to administer the cover pool independently. ${ }^{32}$ Congress may consider new covered bond legislation, but until that occurs, the prospect for covered bonds as a funding source remains limited.

\section{Basel III}

Our participants also described the new set of reform measures contained in Basel III as a source of uncertainty for their funding decisions. The agreement, by the Basel Committee on Banking Supervision in September 2010, called for Basel III implementation to be phased in between January 2013 and January 2019. In the U.S., the Federal Reserve System, the Office of the Comptroller of the Currency, and the FDIC issued three notices of proposed rulemakings in June 2012 describing new regulatory capital rules. Final rules were published in 2013.

The Basel Committee also recently issued revised liquidity standards in January 2013 and expects national regulators to begin phasing them in beginning January 2015. In the U.S., federal banking regulators have stated that they "expect to propose rules to implement Basel III liquidity provisions in a separate rulemaking." ${ }^{, 33}$ In that rulemaking, federal regulators will face the added complication of reconciling the Basel liquidity standards with the liquidity stress testing requirements mandated by the Dodd-Frank Act. As Basel rules are finalized and implemented, our participants believe they will likely have to adjust funding strategies in the face of changing incentives.

\footnotetext{
${ }^{32}$ See, for example, H.R. 940, A Bill to Establish Standards for Covered Bond Programs and a Covered Bond Regulatory Oversight Program, and for Other Purposes (introduced in the U.S. House of Representatives; 8 March 2011). 112th Cong., 1st session, Congressional Bills, GPO Access, March 5, 2013, at www.gpo.gov/fdsys/pkg/BILLS-112hr940ih/pdf/BILLS-112hr940ih.pdf.

${ }^{33}$ See "Basel Committee Revises Basel III Liquidity Coverage Ratio," Client Memorandum, Davis Polk \& Wardwell LLP (January 17, 2013).
} 
Basel III requirements will affect the market for credit card ABS in different ways, as banks can hold these securities on the balance sheet as both an asset (when a bank is the buyer of the ABS) or as a liability (when a bank is the issuer of the ABS). On one hand, regulatory treatment of ABS as an asset can affect the demand for credit card ABS by banks. On the other hand, regulatory treatment of ABS as a liability may affect the willingness of credit-card-issuing banks to supply credit card ABS to the market. Among the potential regulatory factors affecting supply and demand in the market for credit card ABS, two standards stood out in our discussions - the liquidity coverage ratio (LCR) and the risk weight floor for securitizations.

On the demand side, both of these standards could make credit card ABS less attractive for banks to hold on their balance sheets. For example, the LCR requirement is intended to promote improvements to a bank's liquidity risk by ensuring it has enough high-quality liquid assets (HQLA) to meet its liquidity needs for a 30-day stress scenario. Unlike certain government securities, corporate debt securities, and residential mortgage-backed securities, credit card ABS are not included in the calculation of the bank's stock of HQLA. As a result, banks that ordinarily might purchase credit card ABS could face an additional implicit liquidity cost associated with holding those assets.

Additionally, the proposed risk-weight floor for securitizations under the "Standardized Approach" increases the capital charge attached to credit card ABS. Under the old capital rules for securitization, the lowest risk-weight permitted was 7 percent under the internal risk-based model approach (for the largest banks) and 20 percent under the standardized approach. ${ }^{34}$ In the final rule, the regulatory agencies set a supervisory risk-weight floor or minimum risk-weight for a given securitization of 20 percent. ${ }^{35}$ Thus, all else equal, the added liquidity and capital charges associated with the Basel III

\footnotetext{
${ }^{34}$ See "Revisions to the Basel Securitisation Framework - consultative document," Basel Committee on Banking Supervision, Bank for International Settlements, p. 31 (December 2012).

${ }^{35}$ See "Regulatory Capital Rules: Regulatory Capital, Implementation of Basel III, Capital Adequacy, Transition Provisions, Prompt Corrective Action, Standardized Approach for Risk-weighted Assets, Market Discipline and Disclosure Requirements, Advanced Approaches Risk-Based Capital Rule, and Market Risk Capital Rule," 78 Federal Register 62018 (October 11, 2013).
} 
standards regulation may reduce demand for credit card ABS by banks, whose investment portfolios constitute a large part of the market.

On the supply side, the potential regulatory effects are different. While the liquidity coverage ratio contains disincentives for banks as purchasers of credit card ABS on the demand side of the market, it also contains incentives for banks as credit card ABS issuers on the supply side. One participant explained that some of the growth in credit card ABS over the past couple years has been due in part to the term nature of that liability. In the LCR calculation, high-quality liquid assets are expected to cover a bank's net cash outflows over a 30-day period, as funding may run off in a stressed scenario. This benefits credit card ABS as a funding source because its maturity is longer than 30 days. Retail deposits, on the other hand, are assumed to have outflows of at least 3 percent within 30 days under Basel III guidelines. Thus, credit-card-issuing banks may have additional incentive to issue credit card ABS while those same regulations may reduce demand for those assets among other banks. These opposing forces on the market could affect the relative benefits of securitization as compared with other potential sources of funding.

In sum, regulation can affect the relative cost of different funding options for credit card receivables and have the potential to alter an issuing bank's target funding composition. While bank characteristics and market pricing are a large part of funding decisions, our participants pointed to features of pending or potential regulations that create uncertainty and may influence future strategies.

\section{Securitization}

As mentioned earlier, securitization was historically an important source of funding for many credit-card-issuing banks. During the mid-2000s, approximately 60 percent of all commercial bank credit card loans were funded by credit card ABS. ${ }^{36}$ This allocation changed dramatically as the financial crisis froze capital markets and new accounting standards removed the off-balance-sheet treatment of credit

\footnotetext{
${ }^{36}$ See William W. Lang, Loretta J. Mester, and Todd Vermilyea, “Competitive Effects of Basel II on U.S. Bank Credit Card Lending," Journal of Financial Intermediation, 17:4 (2008), pp. 478-508).
} 
card securitizations. ${ }^{37}$ Credit card securitization issuance fell from nearly $\$ 100$ billion in 2007 to about $\$ 7$ billion in 2010, and several banks dropped out of the securitization market altogether, preferring to rely on cheap deposits to fund credit card loans. ${ }^{38}$ Many industry observers at the time wondered if, and when, there would be a rebound in the market. Recently, however, several factors have contributed to growth in credit card securitization despite certain market limitations.

One reason for the recent increase in credit card securitization is the favorable terms and pricing offered to issuers. Our participants explained that the cost of securitizing is near historic lows and in some cases, depending on the costs associated with deposits, securitization is the cheapest funding available in the market. Investors' search for higher-yielding assets in a low-rate environment has played a large role in bringing down the costs of credit card ABS, particularly given the relatively modest supply of new credit card ABS.

According to the Financial Times, in 2012, investor demand exceeded supply to such an extent that foreign credit card issuers looking to tap the dollar-denominated funding market accounted for 14 percent of U.S. issuance. ${ }^{39}$ The Financial Times article also reported that spreads for credit card ABS fell from 93 basis points over Treasuries at the outset of 2012, to 42 basis points by October. Suppliers of new credit card ABS responded to this demand; new issuance in 2012 reached about $\$ 40$ billion, more than double the amount in $2011 .^{40}$

For some credit-card-issuing banks, particularly those rich in deposits, pricing is not the primary reason for issuing credit card securitizations. In addition to the liquidity coverage ratio requirement in Basel III mentioned earlier, our participants described the importance of maintaining a presence in the

\footnotetext{
${ }^{37}$ FAS 166 and FAS 167 are standards issued by the Financial Accounting Standards Board (FASB) that modified the treatment of credit card ABS (and other types of securitized assets) by sponsoring banks. Now, under Generally Accepted Accounting Principles, these assets would remain on the issuer's balance sheet and would affect its riskbased capital requirements.

${ }^{38}$ Data obtained from SIFMA. See http://www.sifma.org/research/statistics.aspx.

${ }^{39}$ See Stephen Foley, "Slice and Dice' Credit Card Deals Return," Financial Times, October 2, 2012.

${ }^{40}$ Data obtained from SIFMA is available at www.sifma.org/research/statistics.aspx.
} 
market. Especially as regulatory supervisors stress the importance of a diversified funding base, creditcard-issuing banks may see the need to maintain at least a minimum level of funding from securitization. One participant said his organization would need to issue at least two ABS deals a year to test access to securitization funding and keep investors interested.

This participant also welcomed the return of more issuers and new issues to the market, as more players can provide the market with certain benefits. Although greater issuance could increase competition among issuers, the market as a whole would benefit through more diversification for investors and added market liquidity. Another participant pointed out that additional players help to spread the infrastructure costs to securitization, including the cost of accounting, legal services, and market research. In the minds of our participants, the desire to maintain a presence in the market and the network benefits that come from greater participation by issuers should contribute to the continuity of the securitization market at or above some baseline level.

Despite these factors and recent growth, the securitization market faces constraints moving forward. Investor demand is strong and credit-card-issuing banks seem more willing to securitize, but the structure of the market has changed since the financial crisis. One participant explained that the securitization market will never return to its 2006 level because there were investor classes that either no longer exist or are seriously diminished. In particular, structured investment vehicles, conduits, and collateralized debt obligations were large investors in ABS, including credit cards, before the financial crisis. These structures bought ABS with money raised from issuing securities to investors, and through credit, maturity, or liquidity transformations, added more investor demand to the market. However, the financial crisis, litigation, and new regulations significantly diminished the role these entities play in the market. 


\section{Deposits}

As a funding source, the relative use of deposits varies over time with economic conditions and lending activity. Recently, with economic uncertainty and a low-rate environment, banks have been flush with deposits. Among credit-card-issuing banks, the growth of deposits over the past few years has allowed them to substitute deposits in place of other funding sources. For example, data from the FDIC's Quarterly Banking Profile show that for credit card banks, deposits as a proportion of net loans and leases rose to 71 percent in 2012, up from 43 percent in $2007 .{ }^{41}$ In the current environment credit-card-issuing banks also face several emerging trends that affect the composition of these deposits. Particularly for those credit-card-issuing banks shifting away from monoline business models, the desire to build stronger and more enduring relationships and the increasingly digital nature of banking have impacts on deposit funding.

Given the current relative abundance of deposits, some banks are looking to shift the focus of deposits from a sheer growth orientation to a value proposition for the depositor. One development shared by many of our participants was a desire to build a stronger brand relationship with deposit customers. This objective implies different approaches for different banks. For credit card lines of businesses that are part of larger institutions with extensive branch networks, it means deepening existing deposit relationships through technology and added services. For credit-card-issuing banks without branch networks, however, it means shifting away from brokered deposits, which are easily raised, but lack a direct relationship with the investor. Instead, these banks are growing deposits through retail channels and building new relationships with deposit customers. As the banks expand their points of contact with deposit customers, the benefits of a stronger relationship may translate into less price sensitivity and more stability of the deposit base.

\footnotetext{
${ }^{41}$ The FDIC reports the ratio of net loans and leases to deposits in its Quarterly Banking Profile, which is available at www2.fdic.gov/qbp/. These numbers are the inverse of the FDIC's reported statistics.
} 
In moving toward retail deposit relationships, credit-card-issuing banks without branches tend to start out by introducing Internet-based deposit products to consumers. Unlike the relationship built with brokered deposits, these banks aim to establish direct relationships with depositors by offering branded savings accounts or CDs at an attractive rate well above the rate offered by branch banks - generally 1 percent in the current low-interest rate environment. These banks also benefit from the advantageous cost structure of an online delivery channel.

As described earlier, regulators sometimes view deposits established by this means as more price sensitive, since "rate shopping" depositors will seek out the best return and move deposits to the most competitive offer. However, our participants explained that Internet deposits are becoming stickier (less price sensitive) as a result of two developments. First, more people are migrating their banking relationships online, and customers are opening online deposit accounts for service and convenience reasons rather than for pricing. Second, banks are expanding customer relationships with additional products and services over and above the original deposit account. Branchless Internet banks aim to build "multichannel" relationships with customers that will make their online deposit accounts less price sensitive and more closely resemble the deposits held by traditional bank branches.

One participant said that as banks gain more experience and lower their rates below the psychological barrier of a 1 percent interest rate offer on savings accounts, they expect a gradual attrition of interest rate-sensitive customers who will be replaced by customers who value the other services that come with the account relationship. Over time, a number of our respondents suggested that Internet-based deposits will evolve into a stable, reliable funding channel rather than a quick means of attracting interest rate-sensitive deposits, as may have occurred in the past.

As people gain experience with online banking and Internet-based accounts behave more like traditional bank accounts, the banking industry — including our participants — is questioning the future of online versus branch banking models. On one hand, branch networks create expensive fixed costs, 
while more and more customers are conducting their banking online. Particularly in a low-rate environment with squeezed interest margins, one participant noted that an Internet-based strategy can provide a bank with a lower cost structure than could be obtained by employing a branch channel strategy.

On the other hand, particular segments like small business owners, or sophisticated products like mortgage loans, continue to bring customers to physical branches. One participant shared the belief that the core of any strategy moving forward will be giving customers ample choice. More specifically, banks will need to satisfy customer needs through a combination of smarter ATMs with greater functionality, expanded digital and mobile channels for convenience, as well as a branch network providing personalized customer advice and services. Future deposit strategies will likely fall somewhere between the models of pure Internet banking and traditional branch banking. But it is clear that advances in information and communication technologies have created new opportunities for credit-card-issuing banks, particularly those without branch networks.

\section{Conclusion}

At the outset, the objective of our interviews was to understand how an environment of economic and regulatory uncertainty influences the funding decisions of a diverse set of credit-card-issuing banks. In targeting banks of different sizes and structures, the discussions reflected not only the unique perspective of each bank but also the factors common to the participating credit-card-issuing banks and the broader industry as a whole. Credit card businesses currently face regulatory forces alongside an extraordinary monetary policy environment and are not under significant pressure to grow their balance sheets. Under these conditions, credit-card-issuing banks have both the motivation and the opportunity to examine and alter their funding strategies. In our discussions, several key themes emerged.

Our participants agreed that securitization remains an important component of funding strategy. Similar to the sentiment expressed in the introduction, there continues to be compelling benefits to 
securitization. Each participant, regardless of the level of securitization activity, expressed the desire and need to maintain a minimum presence in the market. Although the level at which the securitization market will plateau is unclear, participants believed the renewed presence of credit card ABS issuance after the financial crisis is not merely a short-term response to attractive pricing.

Furthermore, industry views on deposits and deposit funding are changing to meet the realities of new technology and evolving consumer banking habits. Consumer utilization of Internet banking allows banks to offer more products and services online, which opens up the prospects for branchless credit-cardissuing banks to pursue a relationship strategy to attracting and retaining deposit customers. As a result, many of these banks are developing a holistic approach to deposits that focuses more on a customer's business with the bank and associated relationships than on the funds in an individual deposit. Efforts to strengthen customer relationships are nothing new, but the trade-offs between branch and Internet banking are sure to drive changes in deposit funding in the future.

This paper has presented several factors currently affecting the markets for credit card ABS and deposits, both of which play important roles in the funding strategy of credit-card-issuing banks. In the future, while many of these underlying trends will persist, rising interest rates will eventually present a new set of price and market conditions. The relative use of certain funding sources may change, or alternative sources of funds — such as covered bonds - may emerge that have not yet been broadly utilized. When that occurs, the industry perspectives shared in this paper might provide a foundation for understanding the various influences shaping the funding strategies of credit card businesses. 